\title{
REFERENDO CONSTITUCIONAL
}

\author{
CONSTITUTIONAL REFERENDUM
}

Área: Direito Constitucional. Referendo.

\section{Ivânia Cristina Camim Chagas Modesto ${ }^{1}$}

RESUMO: O presente trabalho tem por objetivo analisar o instituto constitucional do referendo, dentro do exercício da democracia e suas formas com ênfase no Referendo Constitucional. Para tal abordagem, utilizou-se, como metodologia, o método histórico que faz retormar a evolução histórica sobre o tema referendo e suas previsões legais. O instituto do referendo é identificado por alguns autores, na Grécia Antiga e em Roma, com a abordagem nas primeiras expressões de democracia direta, que remontam à organização política das cidades-estado gregas e ao desenvolvimento dos Estados até nos dias atuais. A consagração das consultas populares e a obrigatoriedade em determinados países do Referendo Constitucional cuja relevância material seria a ratificação da Constituição ou a emenda ou a revisão da lei suprema, como na Suíça, na Dinamarca, na Irlanda dá-se com sua obrigatoriedade como instituto em 49 Estados nos Estados Unidos; porém, este instituto é facultativo na Espanha, na França, na Itália, no Reino Unido, por não possuir previsão normativa, embora seja usual em razão do direito consuetudinário. A atual Constituição Brasileira não prevê expressamente a realização de referendo para propostas de emenda ou de revisão constitucional, assim como não acolheu a ratificação da Constituição por meio de consulta popular. Tampouco Portugal traz em sua Constituição da República tal previsão. A existência de referendo constitucional no território brasileiro - país cuja extensão territorial é grande e apresenta, entre outras amarras, o analfabetismo funcional que pesa nas decisões, a desinformação e problemas técnicos da matéria - afasta por completo uma positivação do instituto; isso, porém, não acontece em países Europeus, vez que possuem realidades diferentes em todos os aspectos. Verificou-se, nesse estudo, a consagração da teoria democrática, inclusive no aspecto histórico, e o poder constituinte originário que pertence ao povo, princípio fundamental da soberania popular. Conclui-se que o tema dessa pesquisa torna-se útil, atual e necessário na busca de contornos dentro do Estado

Advogada. Mestranda em Direito pela Universidade Autônoma de Lisboa. 
moderno e da efetiva democracia.

PALAVRAS-CHAVE: Democracia. Referendo Constitucional. Brasil. Portugal.

ABSTRACT: The present work aims to analyze the constitutional institute of the referendum, within the exercise of democracy and its forms, with emphasis on the Constitutional Referendum. For this approach, the historical method was used, the one which resumes the historical evolution on the referendum and its legal provisions. The institute of referendum is identified by some authors, in Ancient Greece and Rome, with its approach to the first expressions of direct democracy, which date back to the political organization of the Greek city-states and the development of States to the present day. The consecration of popular consultations and the obligatory nature of the Constitutional Referendum in certain countries - whose material relevance would be the ratification of the Constitution or the amendment or revision of the supreme law, as in Switzerland, Denmark, Ireland - is made mandatory as institute in 49 states in the United States; however, this institute is optional in Spain, France, Italy, the United Kingdom, as it does not have a normative provision, although it is usual due to customary law. The current Brazilian Constitution does not expressly provide for the holding of a referendum on proposals for amendment or constitutional revision, nor did it accept the ratification of the Constitution through popular consultation. Nor does Portugal have such a provision in its Constitution of the Republic. The existence of a constitutional referendum in Brazilian territory - a country whose territorial extension is large and presents, among other constraints, functional illiteracy that weighs on decisions, lack of information and technical problems in the matter completely rules out a positivization of the institute; this, however, does not happen in European countries, as they have different realities in all aspects. It was verified, in this study, the consecration of the democratic theory, including in the historical aspect, and the original constituent power that belongs to the people, fundamental principle of the popular sovereignty. The presented theme becomes useful, current and necessary in the search for contours within the modern State and effective democracy.

KEYWORDS: Democracy. Constitutional Referendum. Brazil. Portugal. 
SUMÁRIO: Introdução. 1 Democracia e suas origens. 2. Participação popular e o referendo. 3. Democracia brasileira e o referendo. 3.1 Os referendos no Brasil. 4 A democracia portuguesa e o referendo. 4.1 Os referendos em Portugal. 4.2 Os referendos sobre a despenalização da interrupção voluntária da gravidez. 5 Referendo constitucional: positivação nas constituições. Considerações finais. Referências bibliográficas.

\section{Introdução}

Tanto no Brasil, quanto em Portugal, não há uma previsão legal para que se adote o sistema de referendo constitucional; na Constituição Federal Brasileira, o artigo 60 , parágrafo $4 .^{\circ}$, determina não apenas que as alterações constitucionais somente são capazes de ser realizadas por meio de uma proposta de emenda constitucional, apresentada com apoio de 1/3 (um terço) dos parlamentares da Câmara ou do Senado, pelo Presidente da República ou por mais da metade das Assembleias Legislativas, mas também que a matéria não poderá abolir cláusulas pétreas da Constituição, o que inclui a forma federativa do Estado, o voto direto, secreto, universal e periódico, a separação dos Poderes e os direitos e garantias individuais; ademais é vetada sua votação em época de estado de sítio, de defesa ou de intervenção federal.

Em Portugal, a matéria é tratada e também vetada pelo artigo 115, número 4 da Constituição da República Portuguesa, que determina: "4. São excluídas do âmbito do referendo: a) As alterações à Constituição". Para se alterar a Constituição da República Portuguesa, a iniciativa deverá partir dos Deputados da Assembleia da República, a quem compete preparar o projeto de revisão Constitucional (artigo 285); além disso, as alterações à Constituição deverão ser aprovadas por uma maioria de dois terços dos Deputados em efetividade de funções (CRP, artigo 286).

No Brasil, como em Portugal, o sistema de ideias democráticas assegura aos povos direitos fundamentais que são abarcados e assegurados como parte integrante da Constituição do Estado Democrático, não somente como parte dele, mas também como determinantes nas relações e nas decisões para o bem-estar coletivo. A intervenção popular nas decisões do Estado não dá margem à dúvida de que é a sociedade como um todo que rege as transformações. É ela que cria e oportuniza as decisões da coletividade.

Mediante essa abordagem, ou seja, diante da proibição constitucional 
da tratativa de alterações constitucionais frente à participação popular, de figuras como o referendo constitucional, mais especificamente, em um Estado Democrático de Direito, pergunta-se: "É democrático alterar a Constituição por meio de participação popular?"; "há riscos de desvirtuamento dentro desta proposta?".

Diante desses problemas levantados, o objetivo desta pesquisa é desenvolver uma exposição da participação popular na figura do Referendo Constitucional dentro de uma democracia, seja ela direta, semidireta ou indireta.

O presente trabalho justifica-se pela relevância do tema diante de grandes mudanças, em nível mundial, com a participação popular. Nesse contexto, propusemos um estudo histórico-evolutivo e conceitos elementares para melhor compreender o instituto.

\section{Democracia e suas origens}

Na Ciência Política, o exame rigoroso do conceito de democracia sugere o acompanhamento de uma progressão histórica que tem início na Grécia antiga. Com efeito, a partir do século VI, antes da nossa Era, desenvolveu-se nas polis de Mileto, Megara, Samos e Atenas, uma forma de direção da cidade-estado (polis) com base no poder do povo, conformado pelos membros fundadores das cidades, que começaram a participar diretamente da vida política (politeia).

As antigas repúblicas gregas e romanas de vinte e cinco séculos passados, entre as quais se destaca como tipo clássico e Estado ateniense, foram as primeiras manifestações concretas de governo democrático. Foram aquelas experiências as sementes da democracia, que os filósofos antigos e medievais conservaram vivas até que produzissem tempos modernos. ${ }^{2}$

Foram os gregos e os romanos os primeiros teóricos da democracia, entre os gregos Platão, Sócrates, Aristóteles, e entre os romanos Lucrécio, Cícero e Tácito.

Nos Estados helênicos e romanos, como mais tarde nos Cantões da atual

2 MALUF, Sahid. Teoria Geral do Estado. 20 ed. rev. e atual./ pelo Prof. Miguel Alfredo Maluf Neto. São Paulo: Saraiva, 1990. p. 273. 
Suiça, a democracia foi idealizada e praticada sob a forma direta, isto é, o povo governava-se por si mesmo, em assembleias gerais realizadas periodicamente nas praças públicas. Tal sistema era possível em razão do Estado-Cidade, ou seja, a Polis, na Grécia, e Civitas, em Roma serem pequenas, restringindo-se aos limites da comunidade urbana. E, para que a democracia fluisse com plenitude, a população não podia ultrapassar certos limites. Platão, na República, limitava em dois mil o número de cidadãos; e mais tarde, no Diálogo das Leis, admitiu que o número de cidadãos atingisse cinco mil³ .

A democracia era direta, já que o exercício do poder se deu pelo próprio titular, sem necessidade de intermediários; nessa democracia, não se aplicavam as funções administrativas; ela concretizava-se, porém, no âmbito "legislativo" e, parcialmente, na jurisdição.

“[...] [N]ão se pode dizer que a democracia ateniense, nestes moldes, pudesse alguma vez ombrear com a democracia que praticamos hoje"4. O Estado Romano abrangeu a fase monárquica, a fase republicana e a fase dominial. $\mathrm{Na}$ monarquia, em especial, na sua estruturação, incluía a existência de três órgãos: o Rei, a Assembleia Curiata e o Senado. O Curiato mantinha as assembleias populares, mas logo caiu em desuso. Com a expansão territorial do Estado Romano, juntamente às graves crises econômicas e militares, criou-se uma estabilidade da República, que desencadeou a revolução do ano de 509 a.C., a qual não rompera com o passado monárquico, o qual conservou dois dos seus órgãos: as Assembleias Populares e o Senado.

Dando um salto na história, "podemos dizer, em pouquíssimas palavras, que a Idade Média conheceu um conflito quanto ao exercício do poder, porém, é só na Idade Média que vamos encontrar as primeiras manifestações do que viria mais tarde a ser um sistema representativo".

O Estado Medieval possuía uma estrutura estadual, a qual cooperou para a expansão do Cristianismo, na sua projeção político-social. Aqui surge a ideia de Estado para organizar a vida dos indivíduos em sociedade. Seguindo a história, no absolutismo, o exercício do poder foi entregue ao senhor absoluto. A nobreza,

\footnotetext{
3 Ibidem.

4 GOUVEIA, Jorge Bacelar. Manual de Direito Constitucional. 4. ed. rev. e atualiz. Coimbra: Almedina, 2011. p. 179.
}

5 SOARES, Marcos Antônio Striquer. O plebiscito, o referendo e o exercício do poder. São Paulo: Intituto Brasileiro de Direito Constitucional, 1998. p. 18. 
por sua vez, considerava isso positivo, pois a concentração do poder na figura do monarca era uma forma de garantir o controle das terras, e a concentração de poder nas mãos do rei era uma demanda tanto da burguesia em ascensão, quanto da nobreza.

Mais tarde, no instante em que o povo reivindicou novamente o poder, já não tinha condições de exercê-lo, o que provocou a instalação definitiva da democracia indireta ou representativa; no entanto, a democracia direta ainda sobreviveu em alguns Cantões da Suíça, com a participação direta do povo nas questões essenciais de Estado.

Diversos fatores contribuíram para o fim da democracia direta, como, por exemplo, o desenvolvimento da humanidade, o qual impossibilitou a democracia direta; ainda, podemos citar como fato para esse fim, com ênfase, o aumento das cidades e, consequentemente, da população, o que tornou a participação direta dos cidadãos no processo decisório inviável. A manutenção de tal tipo de democracia ficou insustentável; deu-se, pois, lugar a outras práticas governamentais, como a democracia indireta ou representativa e a democracia semidireta.

\subsection{A democracia indireta ou representativa e democracia semidireta}

Neste trabalho, um fato que merece atenção especial é o surgimento da democracia indireta devido à impossibilidade da democracia direta. Ora, se a vontade popular não pode ser expressada por seu titular, por inviabilidade técnica, o novo mecanismo é o contrário do antigo mecanismo, uma democracia indireta ou representativa.

A democracia indireta é aquela em que o exercício do poder ocorre por meio de outras pessoas que não o titular, ou seja, por representantes do interesse coletivo. A democracia indireta surge como consequência natural da evolução do Estado, já que a democracia direta possui amarras limitantes para sua evolução.

A representação é a fórmula pela qual ocorre a decisão do Estado, em que o povo, por meio de seu representante, exerce o poder. Nesse passo, no final do período absolutista, antes, portanto, da Revolução Francesa, o Estado e poder confundiam-se na pessoa do rei: o soberano conserva em suas mãos a força ampla, geral e irrestrita, personificando todos os poderes do "Estado". Talvez a maior definição do poder absoluto do rei venha da frase "L'Etat c'est moi" - atribuída a Luiz XIV, o soberano francês - cuja tradução implica dizer que o Estado era o próprio rei. 
O Estado conheceu, ainda em sua história, o mandato imperativo, por meio do qual o povo controlava as atividades do eleito no exercício do mandato. Essa figura jurídica fora tomada do direito civil e utilizada pelo direito público. Com ela, era possível afirmar-se a identidade entre eleitor e eleito, ou seja, a vontade daquele exercida por este.

A origem do mandato imperativo é remota: inicia-se na Idade Média na França e na Inglaterra com os primeiros Parlamentos ingleses e perdura até 1614. Enfraquecido com o desenrolar da história, "o mandato imperativo foi abolido pela Revolução Francesa em 1789. Tal era o repúdio contra este sistema de controle popular, que a Constituição francesa de 1791 declarava: Os representantes eleitos nos departamentos não serão representantes de nenhum departamento em particular, mas de toda a nação e não lhes poderá ser dado nenhum mandato"6.

O mandato imperativo é um tipo histórico de representação popular, repelida pelo Direito Público moderno; todavia, muitos pensadores denunciavam os excessos e a concentração de poder nas mãos da Monarquia e iniciaram a pregação da alteração deste modelo, com uma clara divisão de poderes entre os líderes de um Estado, desconcentrando-se o exercício da autoridade; porém, é no século XVI, com o ápice do iluminismo, sobretudo nas pregações de JeanJacques Rousseau, John Locke e Montesquieu, que a proposta de uma divisão de poderes se intensifica.

Neste passo, as ideias de representação eram semeadas, e a passagem teorizada por Jean-Jacques Rousseau da ideia de representação teve lugar na história: "Os deputados do povo não são, nem podem ser seus representantes; não passam de comissários seus, nada podendo concluir definitivamente. É nula toda lei que o povo diretamente não ratificar; em absoluto não é lei"’ .

Rousseau dá contorno definitivo ao mandato imperativo, deduzindo-o de um pacto; há total exigência de participação direta do povo para a consolidação da decisão política. A soberania, assim, se mantém inalienável, é formado um liame de responsabilidade entre eleitor e eleito, sendo que no resultado final é o próprio povo o responsável pela aceitação ou rejeição da lei. Há, portanto, um

\footnotetext{
6 RAMOS, William Junqueira. O mandato imperativo. Conteúdo Jurídico, Brasilia/DF: 30 de novembro de 2020. Disponivel em: https://conteudojuridico.com.br/consulta/Artigos/33598/o-mandato-imperativo. Acesso em: 30 nov. 2020.

7 Livro Jean-Jacques Rousseau. Do contrato Social. 2. ed. São Paulo: Abril Cultura, 1978 (coleção Os pensadores). p. 108.
} 
controle jurídico sobre a atividade política do eleito ${ }^{8}$.

Nesse momento histórico, Rousseau é adversário de Montesquieu, atribuindo ao órgão executivo apenas funções administrativas, sem dividir o poder soberano, que é o legislativo. Já a análise realizada por Montesquieu no clássico "Do espírito das leis", de 1748, calcado nas instituições inglesas, tem seu discurso voltado à representação das instituições inglesas. Embora o povo seja capaz para escolher seus representes, não o é para discutir os negócios públicos. "O povo é admirável para escolher aqueles a quem deve confiar parte de sua autoridade. (...) Entretanto, saberá o povo dirigir um negócio, conhecer os lugares, as ocasiões, os momentos e aproveitá-los? Não; não saberá" ". E mais adiante é categórico: “A grande vantagem dos representantes é que são capazes de discutir os negócios públicos. O povo não é, de modo algum, capaz disso, fato que constitui um dos graves inconvenientes da democracia. (...) Ele - o povo - só deve participar do governo para escolher seus representantes, procedimento para o qual é bastante capaz" ${ }^{10}$.

Para esse filósofo, a eleição não passa de mero mecanismo de escolha dos representantes, ou seja, o povo participa do governo somente no ato de votar, selecionando aqueles que devem exercer o poder. Além do mais, quando Montesquieu trata do exercício do poder, propriamente, ele exclui qualquer possibilidade de controle sobre o representante; portanto, dentro da teoria apresentada por Montesquieu, não há lugar para um controle jurídico sobre a atividade política do parlamentar.

Assim, com a Constituição Francesa de 1791 deu origem à representação cujo documento autoriza os parlamentares a exercerem o poder sem necessidade de instruções ou de consultas aos eleitores. Assim, nesse instante, deixou de existir o controle jurídico sobre a atividade política do parlamentar; desse modo, a representação deu-se mediante eleição, que é um processo de seleção de candidatos, representantes do povo e do interesse público.

Neste passo da história, encontramos as limitações e as inviabilidades da democracia direta, como anteriormente colocado; já na democracia indireta, encontramos limitações da representação popular, na qual há somente atividade

8 SOARES, Marcos Antônio Striquer. O plebiscito, o referendo e o exercício do poder. São Paulo: Intituto Brasileiro de Direito Constitucional, 1998. p. 29.

9 MONTESQUIEU. Do espírito das leis. São Paulo: Editora Martin Claret, 2006. p. 24.

10 MONTESQUIEU. Op. Cit. p. 168. 
política, intangível ao controle jurídico dada a distância mantida com o povo e as decisões de Estado. A democracia semidireta aparece como mecanismo para aproximar novamente o povo do poder, como um meio para atingir aquele conteúdo político, não por normas do direito, mas sim pelo próprio titular do poder.

A democracia semidireta, empregada em diversos Estados, apresenta um aspecto intermediário, uma legítima posição de meio termo, relativamente às precedentes, podendo ser definida como a modalidade em que o povo, apesar de governado pelos seus representantes, tem direito de intervir diretamente, em momentos decisivos, na elaboração definitiva da lei e no funcionamento de orgãos estatais.

Residem outras restrições jurídicas importantes na atividade política. Para manter o princípio da soberania popular, assunto central do nosso trabalho, conforme o qual todo o poder emana do povo e em seu nome será exercido, transferindo-se o exercício das funções governamentais aos representantes ou mandatários do povo, há parâmetros jurídicos a que os parlamentares possam se submeter, e, nesse caso, sim residem outras restrições jurídicas importantes à atividade política. Encontraremos o plebiscito e o referendo como instrumentos preciosos de participação popular no processo político.

\section{Participação popular e o referendo}

Os mecanismos institucionais de democracia semidireta mais conhecidos na história são o referendo, o plebiscito e a iniciativa popular. Uma vez que o tema do trabalho refere-se especificamente ao referendo constitucional, discutese primeiro outros institutos inseridos na democracia semidireta, resumidamente.

Os institutos do plebiscito e do referendo possuem características muito semelhantes que os aproximam, dificultando uma distinção entre os mesmos. Ambos dizem respeito a manifestações populares, consultas ao povo, sempre relativas a decisões de poder. Caracterizam a participação direta do povo no poder do Estado.

Nesse contexto, é possível encontrar, na prática, exemplos históricos da palavra "referendo", significando "plebiscito", e vice-versa. Muitos autores usam como elemento diferenciador o tempo da consulta popular. José Afonso da Silva ensina que "o plebiscito visa a decidir previamente uma questão política ou institucional, antes de sua formação legislativa" ${ }^{11}$. Já o referendo consiste

11 SILVA, José Afonso da. Curso de Direito Constitucional Positivo. 22. ed. rev.e atualiz. São

36 - Themis Revista Jurídica • Volume 02 • Número 03 • Jan-Dez 2021 
na consulta posterior a um ato praticado, seja uma lei já aprovada ou medida normativa em curso, embora o objeto da consulta seja matéria de alto conteúdo político-social e o momento da ausculta do povo seja posterior.

Como participação popular, temos, também, no direito brasileiro, a iniciativa popular, sendo esta a forma pela qual os eleitores provocam os órgãos legiferantes para a feitura de normas: os cidadãos têm participação direta na iniciativa da elaboração de leis. Talvez seja o mais significativo instituto da democracia semidireta. É realmente a que mais atende às exigências populares de uma participação efetiva do processo político. A iniciativa das leis dá-se pelo próprio povo.

Essa figura constitucional obriga o Parlamento a legislar, porque, se um determinado número de cidadãos o exige, um projeto de lei determinado será exposto à Assembleia, que deverá examiná-lo e emitir um parecer, bem como discuti-lo e votá-lo.

Ainda dentro da participação popular, foi tentado, no Brasil, o voto destituinte ou recall, ou revogação popular, ou destituição. Essa figura, que teve sua origem no mandato imperativo, não tem albergue na nossa Constituição de 1988, pois trata do instituto da revogação do mandato eletivo, em que o povo tem a possibilidade de fiscalizar seus representantes e, por meiode um referendo proposto por meio de iniciativa popular revocatória, destituí-los.

Além e ainda, tirante o referendo revocatório, temos o veto popular legislativo, instituto que não tem previsão constitucional. $\mathrm{O}$ veto popular tem origem nos princípios constitucionais, especialmente no princípio da soberania popular, estabelecido no artigo 1. ${ }^{\circ}$, parágrafo único, da Constituição da República Federativa do Brasil de 1988. Por meio da manifestação popular, o veto popular caracteriza-se por uma forma espontânea, contrária a uma determinada lei elaborada pelo Legislativo.

Ademais, há mais uma forma de manifestação direta da soberania popular - a ação popular constitucional - já existente no constitucionalismo brasileiro, desde o Império, mantida no artigo 5. ${ }^{\circ}$, LXXIII, da Constituição brasileira de 1988: consiste na possibilidade de qualquer membro da coletividade, com maior ou menor amplitude, invocar a tutela jurisdicional a interesses coletivos.

A ação popular é um remédio constitucional pelo qual qualquer cidadão fica investido para o exercício de um poder de natureza essencialmente política, e

Paulo: Malheiros Editores, 2003. p. 90. 
constitui manifestação direta da soberania popular consubstanciada no artigo $1^{\circ}$, parágrafo único, da Constituição da República Federativa do Brasil. ${ }^{12}$

"A Constituição da República Federativa do Brasil adotou outras formas de democracia participativa, como as consagradas nos artigos 10,11,31, parágrafo $3^{\circ}, 37$, parágrafo $3^{\circ}, 74$, parágrafo $2^{\circ}, 194$, VII, 260, VI, 216, parágrafo $1^{0{ }^{\circ 13}}$.

Embora o valor democrático participativo siga no sentido de atuação crescente dos cidadãos, no encaminhamento decisório-político, deixamos aqui outras formas que poderiam ser abordadas com respeito ao referendo e, quiçá, ao referendo constitucional, pois é também nosso objetivo neste trabalho.

Referendo vem de ad referendum e origina-se da prática, em certas localidades suíças, desde o século XV, como nos cantões de Valais e Grisons, de consultas à população para que se tornassem válidas as votações nas Assembleias cantonais. Com a difusão da prática, o referendo passou a ser sinônimo de consulta popular ${ }^{14}$.

No sentido moderno, a ideia do referendo permanece associada à Revolução Francesa e aos debates entre os defensores da soberania popular, inspirada em Rousseau, e os partidários da soberania nacional, segundo a fórmula de Sieyès ${ }^{15}$.

A ideia é a de que referendo se vincula à deliberação sobre ato prévio dos órgãos estatais, para ratificar ou rejeitar lei já em vigor ou em projeto de lei. Trata-se o referendo de um modo de expressão da opinião ou da vontade do cidadão, em votação livre e secreta, sobre uma medida que foi ou poderá vir a ser adotada pelos poderes constituintes, no plano nacional no Brasil, e em Portugal, no plano nacional, regional ou local, e, ainda, a manifestação sobre tratados da União Europeia.

\footnotetext{
12 SILVA, José Afonso da. Curso de Direito Constitucional Positivo. 22 ed. rev.e atualiz. São Paulo: Malheiros Editores, 2003. p. 460.

13 DA SILVA, José Afonso. Op. Cit. p. 142.

14 BENEVIDES, Maria Victoria de Mesquita. A cidadania ativa: referendo, plebiscito e iniciativa popular. 2 ed. São Paulo: Editora Ática, 1996. p. 34.

15 Ibidem.
} 


\section{Democracia brasileira e o referendo}

A democracia, não obstante de todas as controvérsias que permanecem quanto à sua definição, refere-se a um regime político orientado por princípios fundamentais, como anteriormente já expostos; destarte, a democracia não se molda de uma só vez, em um só momento, porém, pressupõe-se todo um trabalho permanente, com a participação do povo na formação da vontade política do Estado.

"Importante destacar que a democracia brasileira, em um primeiro momento, projeta uma abertura que se iniciou 'de dentro do regime militar' de Ernesto Geisel (1974-1979), com o objetivo de ampliar, de maneira lenta, gradual e controlada, a base de institucionalidade do regime democrático, possibilitando a transferência de poder aos civis" ${ }^{16}$.

As relevantes normas da Constituição Federal de 1988, destinadas ao estabelecimento e à proteção da democracia no Brasil, nos trinta anos, obtiveram êxitos quanto a sua pretensão de eficácia e de adequação; portando, não podemos nos esquecer dos resquícios dos 21 anos de autoritarismo, que sobrevive na atual democracia.

A democracia constitucional brasileira, desde 1988, é representativa e tem como sujeitos principais os partidos políticos, que serão os personagens praticamente exclusivos do jogo político, com uma colaboração bem tímida dos institutos de participação direta dos cidadãos no processo decisório e definitivo governamental.

No Brasil, um país republicano, impõe-se o exercício do poder com responsabilidade, não pertencendo a quem o exerce; por isso, não se deve contrariar os interesses do titular do poder: o povo. Compreende-se que o sistema, frente ao mandato, põe-se como ponto de referência dos demais institutos informadores da República; a partir do mandato que decorre, o representante deve exercer o poder respeitando o Estado, o povo e, também, seus interesses.

Os representantes não ouvem, individualmente, cada cidadão em razão de ser ele o seu representante, mas busca a satisfação dos interesses de uma coletividade; o interesse público é o senhor do parlamentar.

A Constituição brasileira acolhe os postulados da democracia representativa e participativa, por meio dos quais o controle da administração

16 SWENSSON JR, Lauro Joppert. Notas sobre a constituição transformadora democratizante. 30 Anos de Constituição Federal. São Paulo. v. 140, 2018. p. 48/49. 
pública e das políticas, em geral, deve ser efetuado ou pelas instituições que representam os cidadãos ou, de forma direta, por meio de mecanismos de democracia participativa. Foi nesse contexto que as figuras de participação popular são incluídas na Constituição da República Federativa do Brasil.

Como podemos observar, no Brasil, o referendo está positivado no artigo 14, inciso II, CF/88 e na lei n. 9.709/98, juntamente a outras figuras da soberania popular, como o plebiscito, no inciso I, e a iniciativa popular, no inciso III, do mesmo artigo e lei.

Por si, o referendo é a convocação popular à devida manifestação com posterioridade do ato legislativo ou administrativo, cabendo ao povo, pelo voto, aprovar ou denegar. A matéria deverá ser de relevância nacional e de competência do poder legislativo ou do poder executivo.

O referendo é convocado mediante decreto-lei, por proposta de $1 / 3$ no mínimo dos membros que compõem qualquer uma das casas do Congresso Nacional.

É uma figura jurídica constitucional que exige o envolvimento do poder legislativo, em razão de que se cria uma lei que deverá passar pelo referendo, ou seja, é um mecanismo de participação cidadã que toma lugar no processo legislativo já avançado, e o envolvimento dos cidadãos toma um lugar central para o debate e decisão.

Ademais, a Constituição da República Federativa do Brasil de 1988, em seu artigo 60 , parágrafo $4^{\circ}$, define que não será objeto de deliberação, proposta de emenda tendente a abolir, entre outros exemplos, "os direitos e as garantias individuais".

Na história eleitoral brasileira, até os dias de hoje, por apenas duas vezes a modalidade do referendo fora realizada: nos anos de 1963 e de 2005.

Com o desenvolvimento e a crescente complexidade das democracias modernas, a participação exclusivamente direta dos cidadãos nas decisões de assuntos públicos dos Estados tornou-se inviável. A representação passou, então, a ser o principal arranjo através do qual o cidadão delibera sobre questões públicas ${ }^{17}$.

É importante ressaltarmos que - em uma sociedade como a brasileira,

17 INÁCIO, Magna; NOVAIS, Raquel; ANASTASIA, Fátima. Democracia e referendo no Brasil. Belo Horizonte: Editora UFMG, 2006. p. 123. 
marcada por grandes desigualdades, nos planos econômico, social, político, cultural, além das discriminações racial e sexual - as chamadas populares são raridades. A própria política lida com dificuldades com as figuras representativas. A história mostra que foram poucas vezes usadas essas figuras.

Nesta busca para ouvir o povo, em que o referendo é um instituto democrático e de grande relevância jurídica ou política, temos que, em diversas situações políticas, o povo poderia ser chamado a decidir, mas os custos altos envolvidos e as matérias de alta relevância política afastam a figura constitucional desaparelhada. A prova disso é o fato de que houve somente dois referendos em todo o período de história brasileira.

\subsection{Os referendos no Brasil}

O povo brasileiro não está acostumado a referendos. Diferentemente, por exemplo, do que acontece no Estado da Califórnia (EUA), que precisa de um órgão específico para computar e manter a contabilidade dos números de referendos; de fato, não é um privilégio somente desse Estado, pois o Texas apresenta um número elevado de referendos, chegando à casa dos 100 mil referendos nos dias atuais; o Estado da Flórida também, à casa dos 100 mil referendos. Há uma tradição de consultas estaduais, e, nos condados, as consultas são diretas, o que contrasta intensamente com o nosso sistema, o qual contém muitas legislações e é totalmente isento de consultas populares.

Ocorreram somente dois referendos em toda a história democrática do Brasil, sendo, pois, raríssimo o evento da transferência do poder decisório do Legislativo para o eleitorado. Na história do Brasil, do nascimento até os dias atuais, a população ouviu falar em referendo somente em duas datas: uma figura de extrema importância para a democracia; e outra completamente fora dos padrões da população brasileira.

Em janeiro de 1963, uma consulta popular foi realizada no Brasil. Alguns autores chamam-na de plebiscito e outros, referendo, decidindo os caminhos do nosso sistema de governo. “A Emenda Constitucional de número 4 de 02.09.1961 chamada de Ato Adicional, havia instalado o parlamentarismo, como meio para evitar poderes presidenciais ao vice, João Goulart, que assumiria o cargo principal na República do Brasil’"18, ou seja, no calor da crise política que desaguaria no

18 SOARES, Marcos Antônio Striquer. O Plebiscito, O Referendo: e o exercício do poder. São Paulo: Instituto Brasileiro de Direito Constitucional. Editor Celso Bastos, 1998. p. 97. 
regime militar, a população foi chamada a decidir sobre o sistema de governo: parlamentarismo ou presidencialismo. O sistema parlamentar foi adotado no país, após a renúncia de Jânio Quadros, para enfraquecer o então presidente João Goulart; contudo, a manutenção do novo regime ficou condicionada à realização de um plebiscito ou de um referendo para se decidir qual seria o sistema de governo a ser adotado em definitivo no Brasil. A vitória foi a do presidencialismo, derrotando o parlamentarismo por um resultado largamente favorável ao presidencialismo. "Dos 18 milhões de cidadãos existentes à época, mais de 11,5 milhões votaram e, destes, 9,4 milhões manifestaram-se favoráveis à reinstalação do sistema presidencialista no país". ${ }^{19}$ No dia 06 de janeiro de 1963 , foi rechaçado o então sistema de governo, e o povo optou pelo presidencialismo; houve manifestação de autoridade para o encaminhamento político da vontade popular.

Em um segundo momento, no ano de 2005, a população volta às urnas para um segundo referendo. O referendo sobre o desarmamento foi uma experiência única, não somente porque o Brasil não tinha o hábito de realizá-lo. Foi excepcional em razão da reviravolta a curto prazo na história da consulta: políticos e partidos não se manifestaram abertamente, mas foram substituídos ou até municiados pelos lobistas e pelos grupos de pressão de ambos os lados, de acordo com interesses políticos da época, sem se deixar de sinalizar que a comunicação eletrônica fora uma novidade para a população, que não estava acostumada com o processo. Foi um modo de fazer política inovador.

O Congresso Nacional sobre o projeto de lei do Senado Federal, n. 292 de 1999, deu origem ao Estatuto do Desarmamento; sobre o projeto de decreto legislativo do Senado Federal, n. 950 de 2003, autorizou o Referendo nacional relacionado ao comércio de armas de fogo e munição no país, envolvendo campanhas publicitárias pelo "sim" - "Por um Brasil Sem Armas" - e pelo "não" - "Pelo Direito à Legítima Defesa". A lei n. 10.826 de 22 de dezembro de 2003 dispõe sobre registro, posse e comercialização de armas de fogo e munição, sobre o Sistema Nacional de Armas (SINARM), que define crimes e dá outras providências.

Assim, “em 23 de outubro de 2005, aconteceu o Referendo, e não abordou questões de engenharia político-institucional, mas relacionou-se à segurança pública, à violência e à criminalidade questões de ordem social que ocupam, há

19 INÁCIO, Magna; NOVAIS, Raquel; ANASTASIA, Fátima. Democracia e Referendo no Brasil. Belo Horizonte: Editora UFMG, 2006. p. 77. 
tempos, o topo na lista das preocupações cotidianas da sociedade brasileira"20. Os cidadãos foram chamados a responder precisamente: "O comércio de armas de fogo e munição deve ser proibido no Brasil?". Aproximadamente $64 \%$ dos votantes manifestaram-se contrários à proibição, e apenas $36 \%$ a favor. Nas sociedades contemporâneas, a defesa do indivíduo é dever do Estado e direito do cidadão. A vida civilizada pressupõe a cessão de áreas de soberania ao Estado que passa a ser aquele aparato que detém o monopólio do uso legítimo dos meios de coerção, em um determinado território.

O liberalismo e a democracia combinam-se, quando é resguardado o direito de os cidadãos decidirem - diretamente ou por meio de seus representantes - quais direitos querem manter, na esfera privada da vida, e quais outros querem transferir para a esfera pública. No caso em questão, no referendo sobre o desarmamento, os cidadãos puderam decidir livremente quais direitos queriam manter na sua esfera privada e quais direitos queriam transferir para a esfera pública.

Com o país divido, já que esse referendo, especificamente, marcava uma instabilidade política do partido que estava no governo, a oposição e a população ficaram muito conturbadas, já que as próprias pesquisas apontavam o "sim" com mais de $60 \%$, porém, como dito anteriormente, quem "ganhou" foi o "não"; assim, a votação refletiu muito mais uma insatisfação política-partidária do que, propriamente, a matéria que estava sendo discutida. Um dos rumos por que a população votou pelo "não" foi à busca pela solução do problema da violência generalizada na sociedade brasileira; instigada, esta votou pelo processo decisório nacional.

Com tais apontamentos, não é comum no Brasil que a população seja convocada a tomar decisões políticas que, corriqueiramente, cabem aos representantes nacionais. Ademocracia no país, no âmbito federal, é eminentemente representativa, embora mecanismos de participação popular, como já assinalados anteriormente, são permitidos tanto pela Constituição de 1946, quanto pela atual, promulgada em 1988, apesar de tais dispositivos constitucionais na história da democracia brasileira não serem usuais.

20 Ibidem. 


\section{A democracia portuguesa e o referendo}

Tomando como ponto de partida o advento do constitucionalismo liberal com a Revolução de 1820, na evolução histórica do constitucionalismo Português, houve referendos em momentos monárquicos (1820-1910), mesmo que não tenham sido objeto de propostas formais; na República (1910-1926), tiveram lugar as primeiras experiências de referendos locais e, na ditadura do "Estado Novo" (1926-1974), destaca-se que houve um plebiscito constitucional de 1933.

Conforme nos ensina Antônio Felípe em sua obra "O Referendo na Experiência Constitucional Portuguesa",

[...] em 03 de outubro de 1910 foi desencadeada a Revolução Republicana. Apesar da indefinição ou desânimo da oficialidade, a revolta contou com uma forte determinação de praças e sargentos do Exército, o próprio Exército, navios de guerra e seguido da população civil de Lisboa, alcançaram a vitória, ou seja, as forças republicanas aboliu uma Monarquia de oito séculos e proclamaram em 05 de outubro um regime republicano, fortemente apoiado pela população da capital ${ }^{21}$.

Em 19 de julho de 1911, a Assembleia Constituinte sancionou a revolução, de 05 de outubro de 1910, e decretou, como forma de governo, a República Democrática. Muitos debates foram seguido em razão do projeto de Constituição e, resumidamente, terminaram em 21 de agosto de 1911, como a data da Constituição da República Portuguesa.

Embora o referendo nacional não tenha sido consagrado na Constituição de 1911, a questão esteve sempre presente no debate constitucional; muitos projetos foram apresentados com o tema "referendum", não somente o referendo nacional, mas o referendo local também.

O Referendo Local chegou a ser usado na $1^{a}$ República Portuguesa como meio de limitar a capacidade de decisão dos órgãos autárquicos, sobretudo em matéria financeira; tinha um caráter totalmente diferente daquele que viria a ser usado e consagrado pelo regime democrático a partir de 1982, segundo o qual, a

${ }^{21}$ FILIPE, António. O referendo na experiência Constitucional Portuguesa. Coimbra: Almedina, 2016. p. 105. 
matéria tributária e financeira estão excluída das matérias que tratam o referendo local $^{22}$.

Caminhando rapidamente na história, a ditadura fascista do Estado Novo durou de 1926 a 1974; e, em 21 de fevereiro de 1933, foi publicado o decreto $n$. 22.229, que marcou o primeiro plebiscito nacional, o qual tinha como matéria a Constituição Política da República Portuguesa. O plebiscito à Constituição de 1933 não foi, nem sequer na aparência, um ato de expressão da vontade popular; nas palavras de Mário Soares, em sua obra "Oposição e Governo em Portugal”,

[...] a Constituição de 1933 constituiu apenas um expediente jurídico para mascarar a estrutura ditatorial do ato, pois o texto constitucional não resultou de qualquer Assembleia Constituinte que tenha sido designada para a sua elaboração, e o plebiscito, figura da participação popular fora interposto que funcionou como título de legitimidade formal ${ }^{23}$.

Esta Constituição seria revista em 10 (dez) anos e poderia ser antecipada a sua revisão para 5 (cinco) anos, se fosse aprovada por dois terços dos membros da Assembleia Nacional. A Constituição de 1933 não continha, na sua redação originária, qualquer disposição que contemplasse o referendo nacional; porém, mantinha a previsão do referendo local e de âmbito nacionale e chegaria a obter, portanto, a consagração em sede de revisão constitucional.

Constituição de 1933 definia o Estado Português como uma República unitária e corporativa, o que determinava a relação entre a metrópole e o ultramar. Dada a evolução econômica da Europa, fora proposto dois referendos, sendo um para definir a política ultramarina e outro para acabar com o Estado corporativo. Sendo o resultado desses referendos que determinaria as opções da futura Assembleia Nacional em matéria de revisão constitucional ${ }^{24}$.

De acordo com António Filipi,

\footnotetext{
22 FILIPE, António. Op. Cit. p. 146-147.

23 SOARES apud FILIPE, António. O referendo na experiência Constitucional Portuguesa. Coimbra: Almedina, 2016. p. 159.

24 SOARES apud FILIPE, António. Op. Cit. p. 179-180.
} 
[...] a única 'consulta popular' realizada durante a ditadura foi o plebiscito à Constituição de 1933, organizado para dar uma legitimação formal à Constituição fascista. Para além desse simulacro de referendo, o regime nunca considerou seriamente a realização de qualquer tipo de consulta direta, nem mesmo para as revisões constitucionais ${ }^{25}$.

"Em 1974, o descontentamento e a contestação popular ao regime foi decisiva e em 25 de abril do mesmo ano, o Movimento das Forças Armadas, coroando a longa resistência do povo português e interpretando os seus sentimentos profundos, derrubou o regime fascista" ${ }^{26}$. Com isso, fora derrubada a ditadura de quase meio século e abriu-se o caminho para a construção de um regime democrático em Portugal.

O papel do referendo na democracia portuguesa, de 1974 a 2015, durante a elaboração da Constituição pela Assembleia Constituinte, eleita em 25 de abril de 1975 , teve abordagens para que as propostas, que visavam à aprovação de uma Constituição, fossem submetidas por um referendo e que a Constituição pudesse ser revista por meio do referendo.

Em outubro de 1980, nas eleições legislativas junto àAliança Democrática, reforçou-se a sua maioria absoluta. O resultado eleitoral garantiu ao governante liberdade, mas não total, já que permitia governar, mas não autorizava rever a Constituição.

Muitas propostas foram enviadas para Assembleia, junto a muitos projetos de revisão constitucional, e muitos estudos apresentados por professores, como os da Universidade de Coimbra - Antônio Barbosa de Melo, José Manuel Cardoso da Costa e José Carlos Vieira de Andrade -, foram destinados a servir de base ao projeto de revisão constitucional da Aliança Democrática, publicado sob o título "Estudo e Projeto de Revisão da Constituição da República Portuguesa de $1976 "$.

Com todos os esforços desempenhados, a verdade é que o referendo de revisão constitucional nunca obteve consagração no regime democrático português.

O instituto referendo é consagrado no artigo 115 da Constituição da República Portuguesa, e são três os grupos de referendo, o referendo no âmbito

\footnotetext{
25 Soares apud FILIPE, António. Op. Cit. p.181.

26 REIS apud FILIPE, António. O Referendo na Experiência Constitucional Portuguesa. Coimbra: Almedina, 2016. p.181.
} 
Nacional, o no âmbito local e o no âmbito regional. A lei orgânica do regime de referendo n. 15-A de 1998 e suas alterações regem os casos de referendo em âmbito nacional. Já a lei orgânica n. 4 de 2000 rege os casos e os termos da realização do referendo de âmbito local, previsto no artigo $240^{\circ}$ da Constituição da República Portuguesa.

Em âmbito local e nas consultas diretas das regiões administrativas, também com previsão constitucional no artigo $256^{\circ}$ da Constituição da República Portuguesa, é objeto do referendo questões de relevante interesse nacional, que devam ser decididas pela Assembleia da República ou pelo Governo (artigo 118, número 2 da CRP). Há, assim, a caracterização do instituto como instrumento de participação direta do cidadão no processo legislativo, o qual consegue dar objetividade ao instituto.

Os princípios balizadores do referendo são os mesmos eleitorais, conforme o artigo 113 da Constituição da República Portuguesa. O referendo somente poderá versar sobre uma só matéria. As formulações das perguntas deverão ser objetivas, claras e precisas, e, ao povo, não cabe a opção quanto ao caminho a se tomar, mas somente aceitar ou rejeitar uma proposta, ou seja, um simples "sim" ou "não".

O referendo só tem efeito vinculativo, quando o número de votantes for superior à metade dos eleitores inscritos no recenseamento. Frente à soberania nacional, o resultado do referendo é a própria unidade do Estado, é a vontade do povo; entretanto, se esse número não for atingido, o resultado do referendo servirá apenas como recomendação popular, que será encaminhada ao governo. Portugal, diferentemente do Brasil, tem previsão de referendo local como dito anteriormente.

Desde a entrada em vigor da Lei número 49/90, de 24 de agosto, que regulou a realização de consultas locais, até ao final de 2014 registraram 44 deliberações de orgãos autárquicos requerendo ao Tribunal Constitucional a apreciação da constitucionalidade e legalidade de referendos locais. O Tribunal Constitucional pronunciou-se pela insconstitucionalidade e/ou ilegalidade dos referendos propostos em 39 casos. Apenas cinco foram admitidos ${ }^{27}$.

Há também referendos regionais em relação aos quais, a partir de 1982, a Constituição - como acima já ventilado - passou a prever a possibilidade de

${ }^{27}$ REIS apud FILIPE, António. Op. Cit. p. 352. 
realização de consultas diretas sobre matérias da exclusiva competência das autarquias locais, as quais decidem assuntos das regiões administrativas.

Ao tempo de toda a militância da história portuguesa, inclusive na Revolução de 1974 e após a aprovação da Constituição de 1976, o referendo constitucional, como nos ensina Jorge Miranda e Rui Mederios, passou a ser um instituto procurado pelos opositores das transformações econômicas, sociais e políticas constitucionalmente consagradas. Houve tentativas para a revisão constitucional por meio do recurso ao referendo.

As previsões referendárias portuguesas também são condicionadas a muitos requisitos formais, como decisões parlamentares majoritárias, e o referendo não poderá coincidir no tempo com atos eleitorais de âmbito nacional, para que não haja confusão nos comportamentos eleitorais. As perguntas têm que incidir somente sobre uma matéria e conter, no máximo, três questões, que devem ser formuladas com objetividade, clareza e precisão, para respostas de "sim" ou "não". De fato, as campanhas são muito dispendiosas.

A decisão de convocar o referendo compete, por sua vez, unicamente ao Presidente da República, e essa decisão é livre e inultrapassável. Acresce que o Presidente da República só pode convocar um referendo se este não for declarado inconstitucional ou ilegal pelo Tribunal Constitucional e essa fiscalização prévia é obrigatória ${ }^{28}$.

Essas exigências e muitos requisitos requerem alto custo com campanhas, demonstrando que o instituto é escasso no sistema da República Democrática Portuguesa; desde a sua consagração constitucional, foram realizados somente três referendos nacionais.

\subsection{Os referendos em Portugal}

Como assinala António Filipe, “embora não se possa falar de uma tradição referendária em Portugal, é inegável que as polêmicas políticas e constitucionais que envolveram o referendo e os referendos nacionais e locais efetivamente realizados constituem uma relevância importante para a história política Portuguesa"29.

\footnotetext{
$28 \quad$ REIS apud FILIPE, António. Op. Cit. p. 615.

29 REIS apud FILIPE, António. Op. Cit. p. 15.
} 
De 46 propostas de referendo apresentadas no Parlamento, somente oito propostas aprovadas e três referendos realizados com níveis de participação muito reduzidos. O entusiasmo, apresentado durante as apresentações das propostas, deu lugar a um descrédito, já que a população não aderiu. De acordo com os números apresentados no primeiro referendo realizado em democracia, registrouse uma participação próxima dos $30 \%$, o que gerou um descontentamento frente aos que apoiam a figura jurídica e contempla, nesse instituto, a prova de uma maturidade democrática, a cidadania participativa.

\subsection{Os referendos sobre a despenalização da interrupção voluntária de gravidez}

Em "08 de março de 2007 em consequencia do resultado o referendo realizado em 11 de fevereiro do mesmo ano, tivesse sido aprovada a lei n. 16/2007, de 17 de abril, que excluiu a ilicitude nos casos de interrupção voluntária da gravidez, foi percorrido um longo caminho feito de muitos debates dentro e fora do Parlamento" 30.

O regime democrático português criminalizava o aborto, exatamente no Código Penal Português de 1852, que vigorou até 1982, e determinava pena de prisão de 2 a 8 anos, sendo condenada em igual pena a mulher que consentisse ou fizesse uso desses meios ou que voluntariamente procurasse o aborto em si mesmo, seguindo, efetivamente, o mesmo aborto, conforme artigo $358^{\circ}$ do Código Penal Português.

Em Portugal, realizaram-se, até hoje, três referendos nacionais: dois sobre interrupção voluntária da gravidez e um sobre a regionalização, mas nenhum deles teve a participação de mais de 50\% dos eleitores. De acordo com a Constituição da República, o referendo só tem efeito vinculativo, quando o número de votantes for superior à metade dos eleitores inscritos no recenseamento.

Em 28 de junho de 1998, realizou-se o primeiro referendo sobre a interrupção voluntária da gravidez. O tema marcou a agenda política portuguesa com grande intensidade e com debates acalorados, desde o início dos anos oitenta.

A partir de 1998, a decisão de despenalização do aborto quando praticado por decisão da mulher passou a ficar indissoluvelmente ligado ao referendo. $\mathrm{O}$ referendo sobre a interrupção voluntária da gravidez foi também a experiência

30 REIS apud FILIPE, António. Op. Cit. p. 453. 
mais relevante para aferir a importância deste instituto para os partidos políticos, para os eleitores e para o sistema político português ${ }^{31}$.

No primeiro referendo, a pergunta colocada aos portugueses era a seguinte: "Concorda com a despenalização da interrupção voluntária da gravidez, se realizada, por opção da mulher, nas 10 primeiras semanas, em estabelecimento de saúde legalmente autorizado?" Votaram apenas 31,9\% dos eleitores inscritos, e o "não" ganhou com 50,9\% dos votos, sendo a participação dos portugueses muito aquém das expectativas criadas.

Ressaltamos que, mesmo diante de todas as sondagens publicadas anunciarem a vitória do "sim", os partidos ficaram totalmente divididos entre o "sim" e o "não". De fato, uma direita mais fortemente empenhada e secundada pelo ativismo associado à Igreja Católica acabou por traduzir uma vitória tangencial do "não", contrariando a generalidade dos estudos.

Em fevereiro de 2007, nove anos mais tarde, no governo socialista liderado por José Sócrates, revelou-se que os portugueses voltaram, por meio do referendo, a responder a mesma pergunta; dessa vez, votaram 43,57\% dos eleitores inscritos, tendo o "sim" vencido com 59,25\% dos votos. Apesar do referendo não ser vinculativo, a lei da interrupção voluntária da gravidez foi alterada no sentido aprovado em consulta popular.

O terceiro referendo nacional, em Portugal, realizou-se em novembro de 1998 e incidiu sobre a instituição em concreto das regiões administrativas. Os defensores da regionalização defendia o cumprimento da Constituição, já que previa a criação de regiões administrativas; já os defensores da resposta negativa constestavam a existência de regiões administrativas, com fundamento na narrativa de que país apresentava uma pequena dimensão territorial e que, com a aprovação, isso representaria para Portugal mais despesas públicas em razão da criação de vários cargos políticos. Assim, o referendo deu-se com a pergunta: "Concorda com a instituição em concreto das regiões administrativas?". Com uma porcentagem dos votantes de $48,1 \%$ de eleitores, $63,52 \%$ deles responderam "não", a regionalização não avançou.

$31 \quad$ REIS apud FILIPE, António. Op. Cit. p. 499. 


\section{Referendo constitucional: Positivação nas constituições}

Em uma sociedade em que a democracia está sedimentada, na participação popular, por meio do referendo, este pode ser o instrumento último de adaptação da Constituição às novas realidades sociais; assim, uma constituição promulgada em 1988, no Brasil, não é mais aquela com centenas de emendas constitucionais, obras do poder reformador e do poder revisor; ademais, uma constituição promulgada em 1976, como a Portuguesa, também não é mais a mesma, com revisões diversas constitucionais - inclusive para moldar Portugal aos princípios da economia de mercado da União Europeia -, ainda mais em épocas como a nossa, com tantas transformações tecnológicas e sociais.

No referendo constitucional, este instrumento jurídico, se previsto, poderá modificar diretamente a Constituição, provocando reformas da letra constitucional; poderá, também, acarretar, indiretamente, a mudança no sentido da norma constitucional; poderá, ainda, revogar uma disposição que poderá adequar a norma constitucional à realidade, um instrumento poderoso, em que o povo participa como intérprete da Constituição.

O bom uso do (plebiscito) e do referendo, além da organização social e política, também depende da representação popular. A democracia direta teve seu fim em face de impossibilidades técnicas que a viabilizassem, o número muito grande de cidadãos que participam do processo decisório nas sociedades contemporâneas; o fato das questões debatidas hoje serem técnicas e complexas, frequentemente e diversificadas; o tamanho do Estado moderno; a falta de formação cultural do cidadão para participar do processo político; a falta de tempo do cidadão para informar-se sobre as questões de Estado são motivos suficientes para não acreditarmos que o povo possa voltar a exercer o poder diretamente, sem a necessidade da representação ${ }^{32}$.

No Brasil, o caminho ainda será longo para um exercício livre democrático, conforme assinalado anteriormente: a extensão territorial é imensa, as camadas sociais são muitas, o analfabetismo funcional é de uma grandeza incompreensível. O referendo sempre foi muito acanhado, como apontado anteriormente, e, ainda levando em consideração as questões financeiras para sua

32 SOARES, Marcos Antônio Striquer. O plebiscito, o referendo: e o exercício do poder. São Paulo: Instituto Brasileiro de Direito Constitucional, 1998. p. 124. 
implementação, é quase zero.

A Constituição de 1988 autorizou o pluralismo político, e o que poderia ser uma sociedade composta de vários grupos de poder tornou-se um centro de conflitos. O cidadão nessa dimensão - que poderia participar por meio do referendo ou, ainda, por meio de outros mecanismos, como o plebiscito, a ação popular, o direito de petição - não consegue usá-los, em razão das amarras políticas, das impossibilidades financeiras e por ser perigoso no entendimento da maioria, pois não se sabe como votar; muitas vezes, não se entendem as perguntas formuladas, não sabendo o que está votando.

O referendo constitucional no Brasil, como já dito e fundamentado, não é possível e está muito longe de acontecer, em razão da gravidade que seria a decisão popular em matéria estritamente constitucional; a população não entenderia a complexidade da matéria. O referendo constitucional em Portugal, por sua vez, é vedado pelo "artigo $115^{\circ}$ da Constituição da República Portuguesa, cabendo exclusivamente ao Presidente da República promulgar a Lei de revisão Constitucional ao órgão de soberania composto unicamente por representantes eleitos em lista apresentadas por partidos políticos rever a Lei fundamental" ${ }^{\prime 3}$.

“Os referendos são mecanismos tímidos em alguns países, e de grande relevância em outros; no atual contexto da Constituição Suíça, preveêm-se, de modo expresso, nos seus artigos $89 .^{\circ}, 89 .^{\circ}-\mathrm{A}, 120 .^{\circ}, 121^{\circ}$ e $123 .^{\circ}$, três tipos de referendo, sendo o constitucional, o legislativo e o convencional" ${ }^{34}$. Os referendos constitucional e convencional são obrigatórios, quando se trata de adesão do Estado em organizações internacionais de segurança coletiva ou a comunidades supranacionais, e a natureza das outras matérias é de caráter facultativo. De fato, a Suíça é o país com o maior número de iniciativas e referendos ocorridos no plano nacional. A Constituição de 1848 é quem deu início à federação prévia; inicialmente, o referendo constitucional era obrigatório.

Suíça vota sim pelo trânsito de mão de obra (2007). Ao analisar o referendo de fevereiro de 2009 pela renovação do acordo sobre o livre trânsito de trabalhadores da UE e dos trabalhadores provenientes de Bulgária e Romênia, recém-aceitos na UE em janeiro de 2007 e que realizaram um referendo constitucional. É

\footnotetext{
ROSÁRIO, Pedro Trovão do; RI, Luciene Dal; HAMMERSCHMIDT, Denise. Direito Constitucional Luso e Brasileiro na Contemporaneidade. Curitiba: Juruá, 2019. p. 21.

34 RODRIGUES, Luís Barbosa. O referendo português a nível nacional. Coimbra Editora, 1994. p. 71.
}

52 • Themis Revista Jurídica • Volume 02 • Número 03 • Jan-Dez 2021 
importante ressaltar que a Confederação Suíça, não é um dos Estados membros da UE, tendo rejeitado, via referendo o ingresso neste organismo em dezembro de 1992. Contudo, por sua proximidade e interesses comuns a política de cooperação entre os países europeus continua gerando acordos, e para validar tais acordos, usou-se o referendo ${ }^{35}$.

Esse referendo, realizado no dia 8 de fevereiro de 2009, reflete a política suíça em relação à UE, em não ser membro, mas utilizar acordos bilaterais, de forma a estabelecer acordos de cooperação mútua; assim, aceitar que novos membros da união circulem pelo território do país, com direito ao trabalho, é uma medida bastante importante e que afirma os interesses suíços nessa relação de cooperação internacional.

Com a campanha realizada dessa forma, a Suíça aprovou, por maioria de $59,6 \%$, a ampliação da permissão de trânsito para trabalhadores de Bulgária e Romênia, reforçando ainda mais sua política de cooperação internacional, via acordos bilaterais com a União europeia.

Já na Irlanda, o referendo constitucional oferece uma visão interessante sobre a forma de convocação, sobre o papel do Estado e sobre a preparação para o referendo. Ao longo do século XX, a Irlanda foi alterando a forma de como ocorrem os referendos. Por essa razão, seu exemplo oferece o formato mais trabalhado do uso desse mecanismo de democracia direta. Essas mudanças ocorridas podem ser consideradas como avanço na utilização do referendo. Outrossim, podem servir de base para maiores estudos sobre o aperfeiçoamento do uso de referendos. É importante frisar que as transformações ocorridas foram causadas por um intenso uso de referendos. O uso constante é a melhor forma de se aprimorar uma ferramenta democrática, assim como esta, e o surgimento de debates torna-se essencial, para que o tema seja cada vez mais discutido.

O exemplo irlandês demonstra como um país pequeno, com pouca tradição de poder político dentro do debate internacional, pode fazer valer seus pontos de vista e a opinião de sua população. Esse ponto fica ilustrado pelos acordos de Sevilha e a Cimeira de Bruxelas; desse modo, o modelo de uso de referendos em democracias representativas ocidentais é considerado como o que se modernizou, criando mecanismos de gestão do processo de convocação do referendo. $O$ fato de não estar previsto na constituição irlandesa traz a convocação de referendos por iniciativa popular, criando um novo possível debate na construção de um modelo,

35 Ibidem. 
que combine a democracia representativa e os mecanismos de democracia direta.

Seguindo no direito comparado, a Constituição italiana prevê expressamente vários mecanismos referendários, sendo o objeto cindido em dois grupos de referendos: o referendo ordinário e os especiais.

Em quaisquer dos grupos, encontramos a presença de referendos constitucionais ou legislativos, e, na contramão do direito comparado, o referendo convencional é expressamente proibido.

O instituto do referendo na Itália, em certo sentido, é tão antigo quanto o direito comunal italiano, isso porque, ainda que de modo incipiente, à época das comunas italianas, os cidadãos caminhavam para os campos reunindo-se em assembleia para deliberar sobre questões importantes para a comunidade, tais como impostos, assuntos administrativos, e sobre a guerra ${ }^{36}$.

"De então, a história do referendo na Itália foi escrita com o antecedente de oito pronunciamentos populares acerca da anexação e autodeterminação de unidades territoriais entre os anos de 1848 e 1870" ${ }^{37}$. A Itália prevê o Referendo Constitucional desde 1947, o mecanismo referendário fora introduzido no ordenamento jurídico italiano com a Constituição da República de 1947; desde então, o instituto é usado em larga escala, a população é orientada nesse sentido e vota com consciência, tanto que, em 2020, os italianos aprovaram, por meio de referendo, a redução do número de parlamentares, uma reforma histórica que reduzirá em um terço as cadeiras no Congresso. O número de deputados e senadores passará de 945 para 600 na próxima legislatura.

Nos anos de 1946 e 1947, foram realizados dois referendos (Onde?? No Brasil? Em Portugal?): um que deferiu legitimidade à Assembleia Constituinte; e outro, para decidir se mantinha a forma monárquica de governo ou se deveria instaurar a República. São vedados referendos para matérias tributárias; tampouco são admitidos referendos que determinem anistia e indulto.

A Dinamarca também é um país que prevê o referendo constitucional na sua constituição explicitamente, bem como o referendo legislativo e o convencional; para o referendo constitucional, não há limites à sua realização.

$\mathrm{Na}$ Irlanda, a "Constituição irlandesa alude expressamente, nos artigos

\footnotetext{
36 SGARBI, Adrian. O referendo. Rio de Janeiro: Renovar, 1999. p. 36/37.

37 Ibidem.
} 
$46 .^{\circ}, 47 .^{\circ}$ e $27 .{ }^{\circ}$, a referendos de tipo constitucional e legislativos" ${ }^{38}$. O referendo Constitucional possui natureza obrigatória, já a realização de outros é facultativa. A Constituição Espanhola de 1978 "afirma que os cidadãos têm o direito de participar nos assuntos públicos diretamente ou através dos representantes que hajam sido livremente eleitos" ${ }^{39}$. A Constituição Espanhola foi ratificada popularmente, e nela estão previstos três tipos de referendos: político consultivo, referendo autonômico e o referendo constitucional com previsão nos artigos $167 .^{\circ}$ e $168 .^{\circ}$; no artigo $168 .^{\circ}$, a Constituição Espanhola prevê que o referendo constitucional é obrigatório, quando se trata de revisões totais ou essenciais do texto constitucional.

A Constituição Francesa possui três tipos de referendos e estão previstos nos artigo $11 .^{\circ}$ e $89 .^{\circ}$, quais sejam: o constitucional, o legislativo e o convencional. Quaisquer dos tipos de referendos abarcados pela Constituição Francesa situam-se, temporalmente, ao final do processo normativo, produzindo sempre os respectivos resultados efeitos vinculativos. A França prevê o referendo constitucional (além do legislativo e do convencional nos artigos $11 .^{\circ}$ e $89^{\circ}$ da Constituição Francesa).

Artigo 11. ${ }^{\circ}$ [Disposições em vigor] O Presidente da República, através de proposta do governo, durante as sessões ou através de proposta conjunta das duas Assembleias, publicadas no Diário Oficial, pode submeter a um referendo qualquer projeto de lei sobre a organização dos poderes públicos, nas reformas relativas à política econômica, social ou ambiental. O Conselho Constitucional não teve a oportunidade de pronunciar-se sobre a questão de saber se a redação procedente do $1^{\circ}$ do artigo $4^{\circ}$ da lei constitucional $n^{\circ} 2008-724$ de 23 de julho de 2008 entra em vigor na sequência da $4^{a}$ da Nação e sobre os serviços públicos que contribuem para a sua efetivação ou que visem à autorização da ratificação de um tratado que, sem ser contrário à Constituição, afetaria o funcionamento das instituições. Quando o referendo é organizado mediante proposta do Governo, este faz, perante cada assembleia, uma declaração que é seguida de um debate. Uma vez que o referendo tenha decidido pela adoção do projeto de lei, o Presidente da República promulga a lei no prazo de quinze dias após a

38 RODRIGUES, Luís Barbosa. O referendo português a nível nacional. Coimbra Editora, 1994. p. 83.

39 ROSÁRIO, Pedro Trovão do; RI, Luciene Dal; HAMMERSCHMIDT, Denise. Direito Constitucional luso e brasileiro na Contemporaneidade. Curitiba: Juruá, 2019. p. 21. 
proclamação dos resultados da consulta ${ }^{40}$.

DA REVISÃO ARTIGO 89. A iniciativa da revisão da Constituição pertence conjuntamente ao Presidente da República mediante proposta do PrimeiroMinistro e dos membros do Parlamento. O projeto ou proposta de revisão deve ser considerado nas condições de prazo previsto no terceiro parágrafo do artigo 42 e votado por duas assembleias em termos idênticos. A revisão é definitiva após ter sido aprovada por referendo. No entanto, o projeto de revisão não é apresentado no referendo quando o Presidente da República decide apresentálo ao Parlamento, convocado em Congresso; nesse caso, o projeto de revisão é aprovado apenas se reunir a maioria de três quintos dos votos válidos. A mesa do Congresso é a Assembleia Nacional. Nenhum procedimento de revisão pode ser iniciado ou instaurado quando é violada a integridade do território. A forma republicana de governo não pode ser objeto de revisão" ${ }^{41}$.

Já o Reino Unido não dispõe de uma Constituição em sentido formal, consequentemente, o instituto jurídico do referendo não possui previsão e não há previsão nem em outras normas.

A democracia na Inglaterra tem um passado longínquo e de belos exemplos para a humanidade. Como exemplo atual, o referendo que tem por nome Brexit (do referendo até a saída da Inglaterra da União Europeia), durou anos, com os contrários e os favoráveis, cada qual com suas opiniões acaloradas; mesmo possuindo somente dois partidos, os cidadãos decidem de acordo com o momento, dispensando, muitas vezes, a técnica que a matéria exige, porém, a pergunta foi feita e a soberania popular fora mantida.

O processo teve origem em grupos da direita da Inglaterra inicialmente minoritários e ganhou força ao longo dos anos 2010. A discussão ganhou contornos mais sólidos em 2016, após a proposta ser aprovada em referendo com $52 \%$ de votos favoráveis dos britânicos, contra $48 \%$ que rechaçaram a saída do Reino Unido da União Europeia ${ }^{42}$.

\footnotetext{
40 CONSTITUIÇÃO. Disponível em: https://www.conseil-constitutionnel.fr/sites/default/files/ as/root/bank_mm/portugais/constitution_portugais.pdf. Acesso: 02 abr. 2020.

41 Ibidem.

42 G1. Do Referendo à saída efetiva, entendo as etapas que concretizaram o Brexit. Disponível em: https://g1.globo.com/mundo/noticia/2020/01/31/do-referendo-a-saida-efetiva-entenda-as-etapas-que-concretizaram-o-brexit.ghtml, Acesso: 02 abr. 2020.
} 
Oficialmente, em 31 de janeiro de 2020, o Reino Unido deixa a União Europeia; porém, não deixando para trás, quanto ao referendo nos Estados Unidos da América, em razão de suas interveções do corpo eleitoral terem nascido de forma totalmente inversa às do Brasil, o federalismo, nos Estados Unidos, é partilhado em diversas esferas federadas de competência, e essas atuam nos Estados com forças sociais, políticas e econômicas.

[...] em seu autêntico sentido, o fundamento da República dos Estados Unidos foi à forma de governo direto puro. Os cidadãos reuniam-se em uma praça depois de configurada uma situação de interesse da comunidade, e a discutiam. Essa assembleia veio a chamar-se town meetings, e seus traços são muito semelhantes à Landsgemeinde suíça ${ }^{43}$.

Os Estados Unidos possuem a instituição do referendo em níveis federal, estadual, e ainda, de incidência infraconstitucional, que envolvia matéria de ordem de gestão financeira, com vistas ao controle da emissão de títulos de dívida pública, bem como de quaisquer atos que pudessem onerar o Estado.

Quanto à sua incidência em matéria constitucional, no contexto atual, pode-se afirmar que o referendo constitucional é, de longe, o mais comum nas instituições referendárias americanas, estando presente com disposição expressa em quase todas as Constituições"44.

O professor Pedro Trovão do Rosário, em seu artigo "Constitucionalismos e Democracias um Paradoxo?", assegura que "maior paradoxo será no entanto a Constituição ser alterada pelos representantes dos cidadãos, sem os consultarem ou obterem a sua concordância expressa antes de procederem à alteração de regras contidas na Lei fundamental. Tal o que ocorre por exemplo em Portugal" 45.

Difícil de comparar Constituições como a brasileira e a portuguesa para a realização de referendo ou referendo constitucional; deveras, são continentes que tiveram realidades e povos diferentes em sua formação. Hoje, Portugal encontra-se inserido na União Europeia, com problemáticas diferentes das nossas; o continente foi palco de guerras; não se pode falar para um povo sobre

\footnotetext{
$\overline{43}$ SGARBI, Adrian. O referendo. Rio de Janeiro: Renovar, 1999. p. 27.

44 SGARBI, Adrian. Op. Cit. p. 33.

45 ROSÁRIO, Pedro Trovão do; RI, Luciene Dal; HAMMERSCHMIDT, Denise. Direito Constitucional luso e brasileiro na Contemporaneidade. Curitiba: Juruá, 2019. p. 21.
} 
referendo frente a outro povo que viveu e vive realidades totalmente diversas. A União Europeia encontra-se em um patamar internacional muito superior ao MERCOSUL. Os processos de integração econômica dos continentes estão em descompasso, o que dificulta, demasiadamente, uma comparação diante dos riscos que o referendo oferece para o Brasil.

O caso especial dos referendos europeus, como assevera o doutrinador António Filipe, "foi um traço comum do processo de integração europeia desde 1972, quando o alargamento das Comunidades Europeias de seis para nove membros foi submetido a referendo em França em 23 de abril”. Vários tratados foram submetidos a referendos, em 2004: a adesão de 10 novos Estados membros deu lugar a nove referendos, com exceção de Chipre, o único Estado membro que não se submeteu a referendo. Existiram referendos em Malta, Lituânia, Eslováquia, Polónia, República Checa, Estónia e Letónia, sendo afirmativos os resultados.

Em 2005, quanto ao "Tratado que Estabelece uma Constituição para a Europa”, após ser assinado, os Estados membros realizaram referendo: a Espanha, em 20 de fevereiro, votou "sim"; a França, em 29 de maio, votou "não"; a Holanda, em $1^{\circ}$ de junho, votou "não"; Luxemburgo, em 10 de julho, votou "sim".

Com as rejeições, não era possível salvar o Tratado Constitucional, e a solução encontrada entre os líderes europeus foi o Tratado de Lisboa, assinado em 13 de dezembro de 2007. O novo tratado deixou cair a fórmula constitucional, mas manteve o Tratado Constitucional. Não haveria mais referendos no processo de ratificação, para evitar riscos de novas derrotas.

Depois de 32 referendos realizados no processo de integração dos Estados europeus, com o Tratado de Lisboa, a ideia de referendo para a integração no bloco foi descartada, ferindo, assim, a participação popular e, consequentemente, a democracia. O referendo como mecanismo democrático fora derrotado, deixando, assim, um direito fundamental de participação dos cidadãos a deriva dentro do maior bloco econômico do mundo.

Muitos países da Europa agem conforme o pensamento do professor anteriormente citado, como a Escócia, que também por meio de um referendo, em 2016, votou pela permanência na Europa: 63\% votaram a favor pela permanência. A Irlanda do Norte e a República da Irlanda também votaram, majoritariamente, pela permanência na União Europeia. 


\section{Considerações finais}

No juízo de valor do instituto, produzido pela doutrina entre as vantagens e desvantagens da consagração do referendo constitucional, sempre esteve longe de se realizar de modo pacífico. Com a positivação do referendo constitucional na Constituição do país, a introdução do princípio da participação popular no governo é condição indispensável para a democracia plena. A participação popular, constante e bem-sucedida na Suíça traduz-se em razão de um povo politicamente maduro, socialmente homogênio e com estrutura estável e moderada.

A Constituição da República Federativa Brasileira de 1988, inspirada nas melhores intenções e modelos democráticos, teve a virtude de incluir o referendo, mecanismo este que foi usado, de forma acanhada, sempre controlado pelos políticos e por profissionais que participam da organização do país; nota-se, assim, que o instituto não é usal no país.

Temos informação sobre consultas populares realizadas pela Câmara dos Deputados e pelo Senado Federal em Brasília de assuntos de temas pontuais da sociedade, porém temas locais, regionais ou, até mesmo, uma população isolada fazem com que a matéria desperte interesse da sociedade, mas sem concretização. No Brasil, é visível que os canais ordinários da representação política apresentamse insuficientes para atenderem aos reclamos das democracias de massas, nesse mundo coorporativo e globalizado. Como abrir espaço para a participação do eleitorado na adoção de decisões de transcendente importância? Como realizar referendo constitucional, sem levar em conta a dimensão do território, as variações climáticas, as variações de grupos étnicos, os fatores naturais ou sociológicos, a realidade social, o analfabetismo, a formação geográfica e histórica do povo brasileiro?

No sistema brasileiro, como instituto de participação política, o referendo enquadra-se no plano de intervenção popular nas medidas político-decisórianormativas. Seu ganho situa-se no fato de que pode ser um canal de incidência sobre matérias sensíveis à comunidade, uma atuação partilhada do poder político; afigura-se, pois, não apenas como um avanço e prova de maturidade democrática, mas também como uma nova forma de direcionar e incentivar o político e a cidadania participativa.

O tema exibe um estudo detalhado e atual dentro do debate jurídico contemporâneo no Brasil. Como instrumento da democracia participativa, sua implementação nos assuntos de governo não seria a solução definitiva para o 
exercício da vontade popular, mas é um instrumento de participação do povo nos assuntos que tragam consequências diretas à vida de cada cidadão.

Vale ressaltar que, no Brasil, há grandes problemas tanto no legislativo, quanto no executivo - quiçá no judiciário - em que a previsão e a aplicação do instituto referendo constitucional não seriam salutares, em razão das questões políticas, partidárias, sociais, territoriais, financeiras, do alto grau analfabetismo funcional; contudo, se a política do referendo fosse usual, se a política da democracia popular tivesse sido desenvolvida dentro do território, seria segura e efetiva a aplicação do instituto, mas isso nunca aconteceu.

A realidade portuguesa e dos demais países europeus apresenta-se com acentuadas diferenças em relação ao contexto brasileiro. O intituto do referendo é plenamente viável dentro da conjuntura política em Portugal, sobretudo por estar integrado na União Europeia. Em Portugal, o referendo ainda tem grandes chances de acontecer inclusive pela sua densidade populacional, sua cultura histórica, sua composição dentro do mercado europeu, de sorte que a taxa de sucesso teria possibilidade positiva.

Com o sistema representativo, o poder do povo tem que ter amparo constitucional, e o Estado deve respeitá-lo por meio de um instituto; a sua lei suprema deve ser avaliada e julgada pelo povo, e outros assuntos ordinários deverão ser aferidos pelo povo, avaliando-se a sua adequação à sociedade.

Não se devem deixar de lado os altos custos de uma eleição para a realização tanto de um referendo, quanto, se possível, de um referendo constitucional; todavia, isso deve ser encarado como um investimento que servirá de arrimo para a conscientização política da população.

\section{Referências bibliográficas}

\section{ABREU, Andréia de et al. Constitucionalismo, democracia, procedimento e} substância. 1. ed. Birigui: Boreal Editora, 2013.

ALMEIDA, Carlos Ferreira de. Contratos V: ineficácia. 6. ed. Coimbra: Almedina, 2019. ISBN 978-972-40-7143-5.

ALMEIDA, Carlos Ferreira de. Contratos VI: ineficácia. 6. ed. Coimbra: Almedina, 2019. ISBN 978-972-40-7925-7. 
BENEVIDES, Maria Victoria de Mesquita. A cidadania ativa: referendo, plebiscito e iniciativa popular. 2. ed. São Paulo: Editora Ática, 1996. ISBN 85-08-03991-3

BRASIL. Constituição da República Federativa do Brasil. Vade Mecum Acadêmico de Direito Rideel/ Anne Joyce Angher, organização. 30. ed. São Paulo: Rideel, 2020. ISBN 978.85.339.5828-9.

FILIPE, António. O referendo na experiência constitucional portuguesa. Coimbra: Almedina, 2016. ISBN 978-972-40-6398-0.

GOUVEIA, Jorge Bacelar. Manual de direito constitucional. 4. ed. rev. e atualiz. v. 1. Coimbra: Almedina, 2011. ISBN 978-972-40-4680-8.

INÁCIO, Magna; NOVAIS, Raquel; ANASTASIA, Fátima. Democracia e referendo no Brasil. Belo Horizonte: Editora UFMG, 2006. ISBN 857041-570-2.

MASSON, Nathalia. Manual de Direito Constitucional. 6. ed. rev. e atual. Salvador: Juspodium, 2018. ISBN 978-85-442-1945-4.

MALUF, Sahid. Teoria Geral do Estado. 20 ed. rev. e atual. pelo Prof. Miguel Alfredo Maluf Neto. São Paulo: Saraiva, 1990. ISBN 85-0200673-8

MAZZUOLI, Valerio de Oliveira. Tratados Internacionais de Direitos Humanos e Direito Interno. São Paulo: Saraiva, 2010.

MELlO, Celso Antônio Bandeira de. Curso de Direito Administrativo. 25. ed. rev. e atual. São Paulo: Malheiros Editores, 2007. ISBN 978-857420-867-1.

MENDES, Gilmar Ferreira; BRANCO, Paulo Gustavo Gonet. Curso de Direito Constitucional. 6. ed. rev. e atual. São Paulo: Saraiva, 2011. ISBN 978-85-02-11012-0. 
MENEZES, Anderson de. Teoria Geral do Estado. 4. ed. rev. e atual. Rio de Janeiro: Editora Forense, 1984.

MONTESQUIEU. Do espírito das leis. São Paulo: Editora Martin Claret, 2006. p. 24.

MORAES, Alexandre de Moraes. Direito Constitucional Administrativo. São Paulo: Atlas, 2002. ISBN 85-224-3148-5.

MORAES, Alexandre de Moraes. Direito Constitucional Administrativo. 13. ed. São Paulo: Atlas, 2003. ISBN 85-224-3352-6.

MULLER, Friedrich. Fragmento (sobre) o poder constituinte do povo. Tradução de Peter Naumann. São Paulo: Editora Revista dos Tribunais, 2004.

NOVELINO, Marcelo. Direito Constitucional. 3. ed. rev. e atual. Rio de Janeiro: Forense; São Paulo: Método, 2009. ISBN 978-85-309-2892-6.

NUNES JÚNIOR, Vidal Serrano. A cidadania social na constituição de 1988: estratégias de posição e exigibilidade judicial dos direitos sociais. São Paulo: Editora Verbatim, 2009. ISBN 978-85-61996-02-4.

PORTUGAL. Constituição, 2018. Constituição da República Portuguesa e legislação complementar. Lisboa: Legit Edições, 2018. ISBN 978-972-8973$52-0$

RAMOS, William Junqueira. O mandato imperativo. Conteúdo Jurídico, Brasilia/DF: 30/11/2020. Disponivel em: https://conteudojuridico.com.br/ consulta/Artigos/33598/o-mandato-imperativo. Acesso em: 30 nov. 2020.

RODRIGUES, Luís Barbosa. O referendo português a nível nacional. [S.1.]: Coimbra Editora, 1994. ISBN 972-32-0635-8.

ROSÁRIO, Pedro Trovão do; RI, Luciene Dal; HAMMERSCHMIDT, Denise. Direito Constitucional luso e brasileiro na Contemporaneidade. Curitiba: Juruá, 2019. ISBN 978-85-362-8552-8. 
SILVA, José Afonso da. Curso de Direito Constitucional Positivo. 22. ed. rev. e atual. São Paulo: Malheiros Editores, 2003. p. 90. ISBN 857420-474-9.

SOUZA NETO, Claudio Pereira de; SARMENTO, Daniel. Direito Constitucional: teoria, história e métodos de trabalho. Belo Horizonte: Fórum, 2012. ISBN 978-85-770-592-5.

SGARBI, Adrian. O referendo. Rio de Janeiro: Renovar, 1999. ISBN 857147-128-2.

SOARES, Marcos Antônio Striquer. O Plebiscito, o referendo e o exercício do poder. São Paulo: Intituto Brasileiro de Direito Constitucional, 1998.

SWENSSON JÚNIOR, Lauro Joppert. Notas sobre a constituição transformadora democratizante. 30 Anos de Constituição Federal, São Paulo, v. 140, 2018, p. 48/49, 31 mar. 2020. 